\title{
THE REFORMS IN SPANISH AND POLISH PUBLIC ADMINISTRATION IN 2010-2015 FROM THE PERSPECTIVE OF NEW PUBLIC MANAGEMENT
}

\author{
Jarosław Ignacy \\ Wrocław Univeristy of Economics, Wrocław, Poland \\ ORCID 0000-0003-1498-5894; e-mail: jaroslaw.ignacy@ue.wroc.pl \\ (C) 2018 Jarosław Ignacy \\ This is an open access article distributed under the Creative Commons Attribution-NonCommercial-NoDerivs license \\ (http://creativecommons.org/licenses/by-nc-nd/3.0/)
}

DOI: $10.15611 / \mathrm{ms} .2018 .4 .06$

JEL Classification: D72, H83, M16, F21, F23

\begin{abstract}
We have witnessed fundamental changes in developmental conditions in the last decade. Their pace is constantly growing, and the increasing dynamics of socio-economic transformations create a new reality. The consequences of the changes affect not only companies, but also public administration. Therefore, the goal of the article was to identify the directions of the reforms of new public management in Polish and Spanish public administration in the years 2010-2015. An analysis of the research results shows that the most important trends of the reforms in Poland included: i) transparency of actions, ii) digital administration and e-government and iii) cooperation between various entities of the public sector, whereas Spanish respondents regarded the following trends as the most important: i) digital administration and e-government, ii) reduction of the public sector, iii) transparency of actions. The results of the research show the progressive convergence of the directions and tools of the reforms in EU countries, while maintaining differences in some aspects of development in particular countries.
\end{abstract}

Keywords: public management, new public management, reforms of public administration in Poland and Spain, strategic management.

\section{Introduction}

Although the world is constantly changing, the scope of these changes has increased in recent years and the pace of changes is constantly growing. Phenomena, such as globalisation, metropolisation or digitisation, are radically changing the nature of the global economy. A progressive integration of national economies, sectors, markets and enterprises inevitably leads to the creation of stronger connections within the global economy [Grant 2011; Drucker 2005, 2009, pp. 72-74; Krupski 2005]. The increase of military tensions and global terrorism, the attempts to influence the results of the elections in the United States and EU countries, the radicalisation of the voters and progressive social stratification, are only some examples showing deep and radical changes around the world. Due to increased network connections, the changes affect not only companies [Kotler, Caslione
2010, p. 12; Box 2011, pp. 115-122, Kaleta 2013, pp. 41-69; Ignacy 2014 pp. 371-377], but also units of public administration [Kuhlmann, Bouckaert (eds.) 2016]. A new quality of developmental conditions requires to change the way of thinking and to look for new foundations of management. Under these complicated conditions, the outlines of new challenges of public administration resulting from a new global economic order based on competition, innovation and enterprise are becoming more and more clear. Although detailed tasks of administration and tools of their execution are constantly evolving due to the changes of developmental conditions, the fundamental essence of activity of administration, that is the satisfaction of social needs, remains unchanged. Analysing the importance and effectiveness of the actions of the public administration, we must remember that combining the limited resources of public administration with the unlimited needs of 
the whole society must lead to inevitable conflict. It is impossible to satisfy the needs of all citizens or members of a given community [Stiglitz 2010, pp. 69-75; Hausner 2008]. This fundamental assumption means that, in the context of fast and deep changes in the environment, the key challenge is not only to determine the main goal of activity of public administration, but to create conditions and identify the solutions that would facilitate its effective execution. Analysing the history of administration, we must realise that although the traditional model of public administration resisted the impact of time for a long time, new social challenges and economic changes in the 1970s exposed many flaws of public administration. At that time, developed countries were more and more affected by repeated recessions and political crises [Brudney et al. 2000, pp. 4-6]. Under these conditions, the criticism of public administration was focused mainly on the increasing public sector, excessive bureaucratisation and lowered efficiency of this model of governing [Naschold, Otter 1996]. It has become a common belief that public administration has grown too much and that the public sector is involved in too many sectors of the economy. This has become an impetus to look for new, more effective solutions within the scope of the management of the public sector and satisfaction of social needs. The solution to the empirically observed faults was supposed to become a market order and the use of the achievements of the private sector. The changes that were supposed to eliminate the flaws of traditional administration were called new public management [Hood 1989, pp. 346-358; Hood 1991, pp. 3-19; Aucoin 1990, pp. 115-117]. Although the deepest reforms were implemented in New Zealand, Australia, Great Britain and the United States, they also aroused interest in Canada, Sweden, Holland and other Western European countries, and in developing countries such as Poland [Lubińska (ed.) 2009, pp. 255-340; Osborne, Gaebler 2005; Hammerschmid, Meyer 2005, pp. 709-733; Mongkol 2011, pp. 35-43; Kluvers, Tippett 2011, pp. 519-527; Dan, Pollitt 2015, pp. 1305-1332].

The problem of the scope, pace and effects of the implemented reforms from the social point of view is particularly important and still topical. The developmental potential under these conditions should be effectively used, giving notable benefits for the whole society.

The assumption of the article was to compare Poland with another EU country of a similar socioeconomic profile. Therefore, Spain was selected based on heuristically distinguished criteria such as: 1) the availability of project data and the number of observations in a given country, 2) the general level of socio-economic development (GDP, inflation, unemployment), 3) the population. Therefore the goal of this article was to identify directions of the reforms of new public management in Polish and Spanish public administration in the period of 2010-2015.

\section{The assumptions of the reforms and instruments of new public management - theoretical aspects}

The reforms defined as new public management were based on a few fundamental assumptions to implement such demands as [Auriacombe 2002]:

- promoting competition in the sphere of provision of services,

- transferring monitoring functions from the bureaucratic sphere to communities,

- focusing on financial results instead of expenditures,

- orientation towards the goals and missions instead of obeying the rules, procedures and regulations,

- redefining inquirers as clients,

- decentralisation of power and promoting the participation in management,

- catalysing cooperation between three sectors.

In theoretical aspects an important source of the basis for new public management has become new institutional economics and other associated theoretical concepts, such as [Zawicki 2011 p. 36; Kuhlmann, Wollmann 2014, pp. 167-172, 207-210]: public choice theory, theory of property rights and transaction cost theory. The common denominator of eclectic theoretical foundations was preferring the art of management instead of the art of administering. Generally, the difference lies in the following: "administering means fulfilling duties, whereas, management means achievement of results" [Zawicki 2011, p. 3, 39; Huges 1994, p. 60]. In this context it must be emphasised that although the role and practical importance of the concept of new management were described by foreign authors, Polish authors, writing about new public management, do it in a general or fragmentary way and that "there is no major publication in our country describing the reforms of new public management" [Zawicki 2011, p. 8]. This is a significant fact because Poland does not belong to the group of leaders in the field of the implementation of the reforms of public management. A consequence of the delays in the absorption of many solutions and mechanisms known in other countries and well-tried in previous stages of development of administration is the lowered efficiency of public management in Poland. Cognitive gap and utilitarian purposes have 
become an inspiration for conducting comprehensive research on public administration in Poland and EU countries.

\section{Research methodology}

The presented research on public administration was conducted by the author within the framework of the all-European research project $\mathrm{COCOPS}^{1}$, originally conducted by a consortium of 11 universities in 10 countries. Later this research was also conducted in other countries including Poland. Finally, a survey form was sent to about 40000 members of senior management of the public sector in 21 European countries. The main goal of the research project was to identify the practices of public management and the scope of the reforms implemented in various EU countries. The research was also supposed to determine the effects and consequences of these phenomena for the public sector and the whole of society. A survey questionnaire was thetool to gather the knowledge within this scope and the respondents made an evaluation using a 7-point Likert scale. It was assumed that public administration elites may have knowledge of implemented reforms, therefore a survey questionnaire was sent to the senior managers. It was applied to uncover information about their personal experiences and views within the scope of public management, reforms of public sector and the effects of fiscal crisis within the five years preceding the research. A common "sampling strategy" was applied in all countries. The survey research, preceded with a pilot run of a research tool, was conducted in 2014-2015, on a research sample of 3040 people belonging to the senior management of Polish public administration. 350 surveys were sent back, which is returning at the level of $11.5 \%$. In accordance with social research methodology, the research sample is regarded as large and the return is sufficient to prepare analyses and reports [Babbie 2004, p. 288].

\section{The changes and tendencies of the reforms in public administration in Poland and Spain - research results}

Conducting a comprehensive empirical research in EU countries allowed to identify the most important reforms of new public management in Polish and Spanish public administration in 2010-2015. Based on descriptive statistics, the main groups of phenomena affecting public administration of selected countries in 2010-2015 were distinguished. In accordance with the hierarchy of answers of the respondents in Poland, the research results are presented in the table below and will be discussed in this order.

The answers of the respondents show that the actions connected with increasing transparency of the actions of particular public organisations were of the highest importance in Poland in the period of 20102015. It should be emphasised that such demands are one of the most important elements of the concept of new public management and the analogous reforms

Table 1. Tendencies of the reforms and their importance in Spanish and Polish public administration in 2010-2015

\begin{tabular}{|l|c|c|c|c|}
\hline \multirow{2}{*}{ Type of reform } & \multicolumn{2}{|c|}{ POLAND } & \multicolumn{2}{c|}{ SPAIN } \\
\cline { 2 - 5 } & $\begin{array}{c}n-\text { number } \\
\text { of observations }\end{array}$ & $\begin{array}{c}\text { Average } \\
\text { value } \\
\text { of importance }\end{array}$ & $\begin{array}{c}n-\text { number } \\
\text { of observations }\end{array}$ & $\begin{array}{c}\text { Average } \\
\text { value } \\
\text { of importance }\end{array}$ \\
\hline Transparency of actions & $\mathbf{2 7 7}$ & $\mathbf{5 . 5 7}$ & $\mathbf{2 6 8}$ & $\mathbf{5 . 0 5}$ \\
\hline Digital administration and e-government & $\mathbf{2 7 4}$ & $\mathbf{5 . 3 4}$ & $\mathbf{2 6 4}$ & $\mathbf{5 . 1 7}$ \\
\hline Cooperation between various entities of public sector & 274 & 5.11 & 268 & 4.56 \\
\hline Focusing on results & 272 & 5.10 & 270 & 4.04 \\
\hline $\begin{array}{l}\text { Reduction of internal bureaucracy/removal of administrative } \\
\text { obstacles }\end{array}$ & 274 & 5.06 & 268 & 4.84 \\
\hline Treating users of services as clients & 273 & 4.97 & 268 & 4.60 \\
\hline Flexible forms of employment & 275 & 4.04 & 265 & 3.32 \\
\hline Extension of the scope of services of public sector & 271 & 3.90 & 260 & 2.93 \\
\hline Reduction of public sector & 279 & 3.79 & 267 & 5.08 \\
\hline Strengthening social participation & 273 & 3.64 & 269 & 3.39 \\
\hline External partnerships and strategic alliances & 270 & 3.59 & 260 & 3.98 \\
\hline Outsourcing & 273 & 3.42 & 268 & 3.72 \\
\hline
\end{tabular}

Source: author's own study on the basis of the obtained research results.

\footnotetext{
${ }^{1}$ You can find more information on www.cocops.eu.
} 
were implemented in other European countries. The average value of the importance of such changes was 5.57. In Spain, the actions aimed at increasing the transparency of the public sector were also a priority in 2010-2015, with the average evaluation of 5.05. The research confirmed that digitisation combined with the development of e-government have taken place in Polish administration in recent years. Such reforms are the part of a broader global trend, which has been changing the character of administration in other EU countries for years. The average evaluation of this phenomenon in Poland was 5.34, and similar results were obtained in Spain, with the average of 5.17.

An analysis of the research results shows that other important changes in the recent period were made within the scope of extending cooperation between various entities of the public sector. In this case, the average value of the importance of such changes in Poland was 5.11 and in Spain was a little lower, at 4.56.

Focusing on the results was one of the most important demands in new public management. In Poland the importance of this trend for the respondents was 5.10. Such changes were less important in Spain with the average of only 4.04. It must be emphasised that another trend realising the demands of new public management in Poland was the change aimed at improving the efficiency of administration. One of the possible solutions is a reduction of internal bureaucracy and removal of administrative obstacles. This happened in Poland, where the average evaluation of importance, in this case, was 5.06. Similar results were obtained in Spain, with the average at 4.84. Another effect of the reforms of public administration implemented in Poland in 2010-2015 was not only changes in the perception of the recipients of services, but also the different specificity of contacts with them. The answers of the respondents show that the users of services are more and more often treated as clients in Poland. Such reforms conform with the assumptions and spirit of new public management. In Poland the respondents assessed its importance at 4.97, therefore it must be treated as an important phenomenon. Analogous changes can also be observed in Spain, with the average at the level of 4.6. The factors mentioned above constitute the group of the most important reforms implemented in public administration in Poland in 2010-2015 (importance was between 4.97 and 5.57 in the 7-point Likert scale). A similar conclusion may be formulated also with reference to Spain (importance between 4.04 and 5.17).

The reforms presented later in this article were regarded by the respondents as moderate phenomena, that is having a moderate impact on Polish public administration. A list of such reforms implemented in Polish public administration starts from flexible forms of employment as one of the fundamental assumptions of new public management. The importance of this factor was assessed at the level of 4.04 in Poland and only 3.32 in Spain.

Another trend observed in Polish public administration is the extension of the scope of services of the public sector. This direction does not conform with the idea and assumptions of new public management, but it is clearly visible in Poland, and the average evaluation of this phenomenon was 3.90. Different results were obtained in Spain, where the average evaluation was only 2.93. From this point of view, it may be surprising that both the extension of the scope of services of the public sector and the opposing trend, that is a reduction of the public sector had a similar impact on public administration in Poland. Its average importance to respondents in Poland was 3.79, while in Spain it was one of the trends of the highest importance, with the average of the answers of the respondents at the level of 5.08. The results of the research illustrate a significant but mystifying phenomenon, in which both opposing processes in Polish public administration are happening at the same time and they are of similar importance. The logic of the reduction of the public sector was dominant in Spain. In order to fully explain empirically the identified phenomena, in-depth statistical research must be conducted. This research must include, among others, the structure of the answers and the level/type of public administration in both countries.

An analysis of the answers of the respondents also allowed to identify changes concerning the mode of action of public administration, particularly increasing the commitment of the citizens. Another trend of the reforms includes strengthening social participation. In Poland the average evaluation of the importance of such changes was 3.64, whereas the importance of social participation was slightly lower in Spain where respondents assessed its average importance at the level of 3.39. The research also confirmed that in the period of 2010-2015, the relations and connections with other entities have also clearly changed, expressed in external partnerships and strategic alliances. The average evaluation of this phenomenon in Poland was 3.59. In Spain this phenomenon was more important, with the average evaluation at 3.98. Another assumption and demand of new public management was a move away from the independent provision of public services to outsourcing and the provision of these services by entities of the private sector. The results of the research show that such 
transformations occur to a relatively small extent and they are of little practical importance. In Poland the average evaluation of this phenomenon was 3.42, whereas this solution was applied more often in Spain, where respondents assessed its importance at the level of 3.72 .

The inevitable research limitations concerning the character of the conducted research should not be ignored while analysing above trends and phenomena. Taking methodological limitations into account, we must remember that the research was conducted based on the survey questionnaire. The answers reflected the views and opinions of the respondents, however it is hard to avoid subjectivity in such research. On the one hand, it is related to the understanding of research statements, and on the other hand, to the given answers. The above research limitations do not make conducting research and the empirically identified practices of Polish and Spanish public administration in 2010-2015 pointless. Although the conducted research is of an initial character, they open new research areas, important both from the theoretical and utilitarian point of view. Within the framework of further research works, we should find the answer to the question about the universal nature of the identified regularities and how characteristic they are for particular levels of public administration. In-depth research may also include a comparative analysis of the tools of management and other practices applied in Polish public administration in comparison with selected EU countries.

\section{Conclusion}

The conducted research allowed to draw a few important conclusions. Generally speaking, the changes in Polish public administration in 2010-2015 conformed to the key assumptions of the new public management. The only exception to this rule was an extension of the scope of services of the public sector. The trends of the reforms of the highest importance included:

1) transparency of actions (average 5.57),

2) digital administration and e-government (average 5.34),

3) cooperation between various entities of the public sector (average 5.11),

whereas Spanish respondents indicated as follows:

1) digital administration and e-government (average 5.17),

2) reduction of the public sector (average 5.08),

3) transparency of actions (average 5.05).

The research results show that the demands and the assumption of new public management are becoming more and more popular in the practice of
Polish and Spanish public administration. This shows a progressive convergence of the directions and tools of the reforms applied in the practice of public administration in EU countries, which can be seen in a similar order and evaluation of the importance of the analysed types of the reforms in Poland and Spain in 2010-2015. However, there are significant differences in some aspects of the practice of public administration in particular countries. They refer to the importance of particular reforms in both countries in the analysed case. The general rule is the fact that the average evaluation of the importance of changes in Spain is slightly lower in comparison with Poland, which shows a slightly lower practical importance of the implemented reforms. The most important exception is the much lower importance of the reduction of the public sector in Poland (5.08 vs. 3.79 in Poland). The specificity of Poland is also formed by the much higher evaluation of the importance of the following reforms: 1 ) focusing on the results (5.1 vs. 4.04 in Spain), 2) the extension of the scope of services of the public sector (3.9 vs. 2.93 in Spain), 3 ) the use of flexible forms of employment (4.04 vs. 3.32 in Spain).

\section{Bibliography}

Aucoin P., 1990, Administrative Reform in Public Management: Paradigms, Principles Paradoxes and Pendulums, Governance, 3 .

Auriacombe C., 2002, Reflections on the New Public Management, Journal of Public administration, vol. 134, no. 2

Babbie E., 2004, Badania spoleczne w praktyce, Wydawnictwo Naukowe PWN, Warszawa

Box T.M., 2011, Small firm strategy in turbulent times, Academy of Strategic Management Journal. Jan vol. 10 issue 1.

Brudney J.L., O'Toole L.J., Rainey H.G. (eds), 2000, Advancing Public Management: New Developments in Theory, Methods, and Practice, Georgetown University Press, Washington.

Dan S., Pollitt Ch., 2015, NPM Can Work: An optimistic review of the impact of New Public Management reforms in central and eastern Europe, Public Management Review, vol. 17, no. 9.

Drucker P.F., 2005, Praktyka zarzadzania, Wyd. MT Biznes.

Drucker P.F., 2009, Zarządzanie w XXI wieku - wyzwania, Wyd. MT Biznes.

Grant R.M., 2011, Wspótczesna analiza strategii, Oficyna a Wolters Kluwer business, Warszawa.

Hammerschmid G., Meyer R.E., 2005, New Public Management in Austria, Public Administration vol. 83, no. 3.

Hausner J., 2008, Zarządzanie publiczne, WN Scholar, Warszawa.

Hood C., 1989, Public administration and public policy: intellectual challenges for the 1990s., Australian Journal of Public Administration 48.

Hood C., 1991, A Public Management for All Seasons, Public Administration, no. 69.

Huges O.E., 1994, Public Management and Administration. An Introduction, The MacMillan Press Ltd., London. 
Ignacy J., 2014, Horyzont czasowy strategii polskich firm w świetle badań empirycznych, Marketing i Rynek nr 5/2014, PWE. Kaleta A., 2013, Realizacja strategii, PWE, Warszawa.

Kluvers R., Tippett J., 2011, The views of councillors and managers on accountability in local government: an empirical study in Australia, International Journal of Management, vol. 28, no. 2, June.

Kotler P., Caslione J.A., 2010, Chaos. Zarzadzanie i marketing w erze turbulencji, New Media, Warszawa.

Kuhlmann S., Bouckaert G. (eds.), Local Public Sector Reforms in Times of Crisis: National Trajectories and International Comparisons, Palgrave Macmillan, 2016.

Kuhlmann S., Wollmann H., 2014, Introduction to comparative public administration: Administrative systems and reforms in Europe, Cheltenham and Northampton, MA.
Krupski R., 2005, Zarzadzanie przedsiębiorstwem w turbulentnym otoczeniu, PWE, Warszawa.

Lubińska T. (ed.), 2009, Nowe zarzadzanie publiczne - skuteczność i efektywność, Difin, Warszawa.

Mongkol K., 2011, The critical review of new public management model and its criticisms, Research Journal of Business Management 5(1)

Naschold F., Otter C., 1996, Public Sector Transformation. Rethinking Markets and Hierarchies in Government, John Benjamin Publishing Company, Amsterdam, Philadelphia.

Osborne D., Gaebler T., 2005, Rzadzić inaczej, Wydawnictwo Media Rodzina.

Stiglitz J., 2010, Ekonomia sektora publicznego, Warszawa, PWN.

Zawicki M., 2011, Nowe zarzadzanie publiczne, PWE, Warszawa.

\title{
REFORMY ADMINISTRACJI PUBLICZNEJ W POLSCE I W HISZPANII W LATACH 2010-2015 Z PERSPEKTYWY NOWEGO ZARZĄDZANIA PUBLICZNEGO
}

\begin{abstract}
Streszczenie: W ostatniej dekadzie jesteśmy świadkami fundamentalnych zmian uwarunkowań rozwojowych. Ich tempo stale się zwiększa, a wzrastająca dynamika przeobrażeń społeczno-gospodarczych tworzy nową rzeczywistość. Konsekwencje zachodzących zmian są odczuwalne nie tylko przez firmy, ale także przez administrację publiczną. W związku z tym celem artykułu jest identyfikacja kierunków reform nowego zarządzania publicznego zachodzących w administracji publicznej w Polsce i w Hiszpanii w latach 2010-2015. Analiza odpowiedzi potwierdza, że w Polsce do trendów reform o największym znaczeniu należały: i) przejrzystość i transparentność działań, ii) administracja cyfrowa i e-administracja oraz iii) współpraca pomiędzy różnymi podmiotami sektora publicznego. Natomiast w Hiszpanii respondenci za najważniejsze uznali: i) administrację cyfrową i e-administrację, ii) ograniczenie rozmiaru sektora publicznego, iii) przejrzystość i transparentność działań. Wyniki badań wskazują na postępującą konwergencję kierunków i narzędzi reform w krajach Unii Europejskiej przy jednoczesnym zachowaniu odrębności niektórych aspektów rozwoju w ramach poszczególnych krajów.
\end{abstract}

Słowa kluczowe: zarządzanie publiczne, nowe zarządzanie publiczne, reformy administracji publicznej w Polsce i Hiszpanii, zarządzanie strategiczne. 